\title{
The Changes of Nutrient Content in Soil in Long-term Fertilizer Experiments
}

\author{
Janis Vigovskis, Aivars Jermuss, Agrita Svarta, Daina Sarkanbarde \\ Research Institute of Agriculture of Latvian University of Agriculture \\ Address: Zemkopības institūts 7, Skrīveri, LV-5125, Latvia
}

\begin{abstract}
The paper describes the influence of long term (more than 30 years) fertilizer application to the changes of soil properties and identifies the influence of different fertilization rates to phosphorus, potassium, calcium and magnesium accumulation in soil.

The research has been carried out at the Research Institute of Agriculture of Latvian University of Agriculture in the long-term subsurface drainage field established in Skrīveri in 1981 under the guidance of professor J. Štikāns. The long-term drainage field was established in the uncultivated gleyic sod-podzolic Hypostagnic Endogleyic Albeluvisol (Hypereutric), stw-ng-AB(he) loam that had not been used in agriculture for 20 years before. The experimental field was established with four rates of mineral fertilizers: without fertilizers, N45P30K45; N90P60K90 N135P90K135 calculated in form of $P_{2} O_{5}$ and $K_{2} O$. Since 1994 a seven-year crop rotation has been organized: 1) winter triticale, 2) potatoes, 3) spring wheat, 4) spring oilseed rape, 5) spring barley + perennial grasses (red clover, timothy), 6) perennial grasses, 1st year of using, and 7) perennial grasses 2nd year of using. Mineral fertilizers were applied according to the anticipated rates of plant nutrient elements annually during the cultivation of soil before sowing. For winter cultivars the phosphorus as superphosphate and potassium as potassium chloride fertilizers were cultivated before the sowing in autumn and nitrogen in form of ammonium nitrate was applied the next spring at the beginning of vegetation and at the stage of tillering. During the vegetation period all the required common agrotechnical measures were taken - treatment with herbicides, fungicides and insecticides.

After 32 years of trial similar soil parameters showed significantly different content of nutrients related to the different level of fertilizer application. On a low background of fertilizers (N45P30K45) a small increase of mobile phosphorus in soil has only been observed in recent years. At the fertilizer rate N90P60K90 the content of available phosphorus and potassium in soil gradually begins to grow. Fertilization norm N135P90K135 caused a constant accumulation of nutrients in soil. In 30 years' time the content of exchangeable phosphorus (calcium lactate extractable) has increased more than 20 times (from 9 till $184 \mathrm{mg} \mathrm{P}_{2} \mathrm{O}_{5} \mathrm{~kg}^{-1}$ ) and exchangeable potassium (calcium lactate - extractable) has increased more than 4 times (from 64 till $223 \mathrm{mg} \mathrm{K}_{2} \mathrm{O} \mathrm{kg}^{-1}$ ). There were no relation between different fertilizing rates and calcium and magnesium content in soil observed.
\end{abstract}

Keywords: mineral fertilizers, phosphorus, potassium, nutrient content, soil.

\section{INTRODUCTION}

In the recent years in the Baltic Sea region there is an increasing attention to the research of the agricultural impact on the environment. The losses of plant nutrients (nitrogen and phosphorus) in agricultural soils are extremely complex and are affected by a number of factors such as soil type, climate, crop rotations and the use of manure and fertilizer. The factors vary in time and space both at field, farm and regional level causing uncertainties in the estimates of leaching. [5,6,11].

Currently, there is general acceptance that soils should contain a certain amount of plant-available phosphorus $(\mathrm{P})$, together with other nutrients, to ensure optimum yields of crops and the efficient use of other annual inputs, especially nitrogen (N) fertilizers [10].
Reducing $\mathrm{P}$ fertilisation did not decrease $\mathrm{P}$ leaching, but the yields decreased [12]. Other similar experiments demonstrated a yield response to $\mathrm{P}$ fertilisation [2].

Calcium and magnesium are vitally important elements. These base elements (cations) are very important not only as plant nutrients. Agrochemical and physical properties of soil depend on the base cations as well. Calcium improves soil properties and thus has a tremendous effect on the growth and development of plants as well as on soil microbial activity. Even in acid soils its amount is 2-3 times larger than that of potassium or phosphorus. Like calcium, magnesium improves the properties of soil, yet high levels of magnesium content impairs soil water regime $[1,8]$.

The paper describes the influence of long term (more than 30 years) fertilizer application to the 
changes of soil properties and identifies the influence of different fertilization rates to nitrogen, phosphorus, potassium, calcium and magnesium accumulation in soil.

\section{MATERIAL AND METHODS}

\section{Field site}

The research has been carried out at the Research Institute of Agriculture of Latvian University of Agriculture in the long-term subsurface drainage field established in Skrīveri in 1981 under the guidance of professor J. Štikāns.

The long-term drainage field was established in the uncultivated gleyic sod-podzolic Hypostagnic Endogleyic Albeluvisol (Hypereutric), stw-ng-AB(he) (IUSS Working Group WRB, 2007) loam that had not been used in agriculture for 20 years before.

The study site is located in the central part of Latvia $\left(56^{\circ} 38^{\prime} \mathrm{N}\right.$; $\left.025^{\circ} 08^{\prime} \mathrm{E}\right)$ with warm temperate climate. The precipitation amount is normally $670 \mathrm{~mm}$ a year. The annual air temperature is $+5.7^{\circ} \mathrm{C}$. The winter average air temperature is $-4.3^{\circ} \mathrm{C}$. The duration of vegetation period proceeds 180-210 days.

The experimental factors were mineral fertilizers, termed ' $F$ '. The experimental field was established with four rates of mineral fertilizers: F0 - without fertilizers, F1 - N45P30K45; F2 - N90P60K90 and $\mathrm{F} 3$ - N135P90K135 calculated in form of $\mathrm{P}_{2} \mathrm{O}_{5}$ and $\mathrm{K}_{2} \mathrm{O}$ or $\mathrm{F} 1-\mathrm{N} 45 \mathrm{P} 13 \mathrm{~K} 37$; F2 - N90P26K74 and F3 N135P39K112 calculated as elemental $\mathrm{P}$ and $\mathrm{K} \mathrm{kg}$ ha 1 . Mineral fertilizers were applied according to the anticipated rates of plant nutrient elements annually during the cultivation of soil before sowing. For winter cultivars the phosphorus as superphosphate and potassium as potassium chloride fertilizers were cultivated before the sowing in autumn and nitrogen in form of ammonium nitrate was applied the next spring at the beginning of vegetation and at the stage of tillering.

The total area (1.6 ha) of the experimental field was divided into 16 plots $(15 \times 50 \mathrm{~m})$. Each plot was supplied with a seepage tile drain at the depth of 80 $100 \mathrm{~cm}$ and an inspection well for drain water sampling and measurement of total water amount.

\section{Crop management}

In the long-term site in Skrīveri winter rye, winter triticale, winter and spring wheat, spring barley, oat pure stand and mixed with peas as well as potatoes, spring oil rape (OSR) and perennial grass (biennial clover and timothy mix) have been grown since 1982 . Since 1994 a seven-year crop rotation has been organized: 1) winter triticale, 2) potatoes, 3) spring wheat, 4) spring oilseed rape, 5) spring barley + perennial grasses (red clover, timothy), 6) perennial grasses, 1st year of using, and 7) perennial grasses 2nd year of using. The crop was the same on all plots. During the vegetation period all the required common agro-technical measures were taken - treatment with herbicides, fungicides and insecticides.

\section{Measurements and calculations}

The area of harvested plot composed $23.2 \mathrm{~m}^{2}(1.7 \mathrm{x}$ $13.6 \mathrm{~m}$ ) for growing grain and OSR. The yield was harvested by direct combining. The straw and other harvest residues were incorporated into the soil. The perennial grass was cut two times during the growing season. The harvested grass-clover (GC) biomass was removed from the plots.

The soil samples were taken in autumn for the analysis of $\mathrm{P}, \mathrm{K}, \mathrm{Mg}$ and $\mathrm{Ca}$. Forty soil samples were taken in each plot at $25 \mathrm{~cm}$ depth using a $12 \mathrm{~mm}$ diameter steel auger, and the samples from each plot were mixed, dried and sieved. Phosphorus and potassium content in soil was extracted from acid calcium lactate, calcium and magnesium- in the $1 \mathrm{M}$ $\mathrm{KCl}$ extract by atomic absorption method.

The obtained data mathematical processing was performed using analysis of variance (ANOVA).

\section{RESULTS AND DISCUSSION}

At the beginning (1981) of the experiment soil properties were $\mathrm{pH}(\mathrm{KCl})$ 4.7-4.9; available phosphorus (DL-method) 10-20 $\mathrm{mg} \quad \mathrm{P}_{2} \mathrm{O}_{5} \quad \mathrm{~kg}^{-1}$; exchangeable potassium (DL-method) 40-60 mg $\mathrm{K}_{2} \mathrm{O}$ $\mathrm{kg}^{-1}$ and soil organic matter 19-21 $\mathrm{g} \mathrm{kg}^{-1}$ (Tyurin's method). After 32 years similar soil parameters showed significantly different content of all nutrients (phosphorus, potassium) related to the different level of fertilizer application.

In variant without fertilizers (F0) available phosphorus and potassium both did not change significantly during the experiment (Figure 1). In 2012 (Table 2) phosphorus content in soil was only $12 \mathrm{mg}$ $\mathrm{P}_{2} \mathrm{O}_{5} \mathrm{~kg}^{-1}$ and characterized as very low. Potassium content was $60 \mathrm{mg} \mathrm{K}_{2} \mathrm{O} \mathrm{kg}$ and characterized as average.

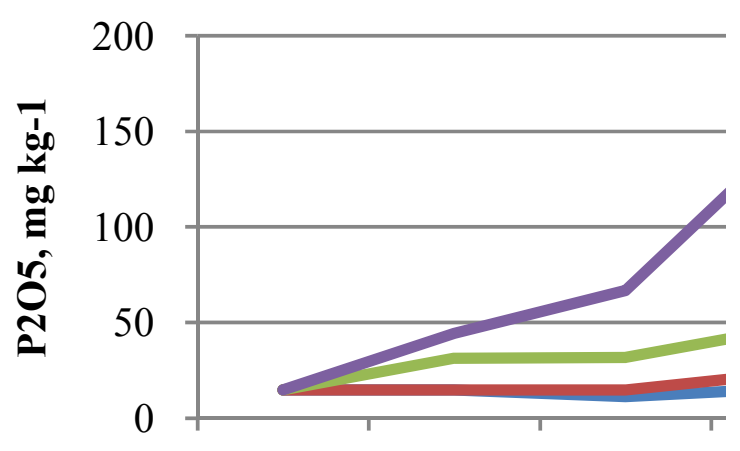

Fig.1. The changes in phosphorus content $\left(\mathrm{mg} \mathrm{P}_{2} \mathrm{O}_{5} \mathrm{~kg}^{-1}\right)$ in soil, 1981-2012 


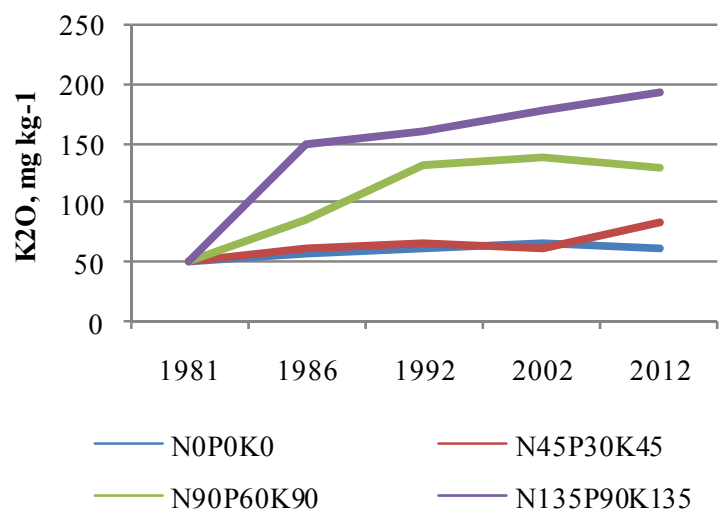

Fig. 2. The changes in potassium content $\left(\mathrm{mg}_{2} \mathrm{O}_{5} \mathrm{~kg}^{-1}\right)$ in soil, 1981-2012

At fertilizer rate $F 1$, available $\mathrm{P}$ only started increasing 20 years after the establishment of the experiment. The rise was insignificant and in 2012 the content of available $\mathrm{P}$ was $29.8 \mathrm{mg} \mathrm{P}_{2} \mathrm{O}_{5} \mathrm{~kg}^{-1}$. Available $\mathrm{K}$ only started increasing in 2002. The content of available $\mathrm{K}$ in case of $\mathrm{F} 1$ variant was 74.8 $\mathrm{mg} \mathrm{K}_{2} \mathrm{O} \mathrm{kg}^{-1}$ in soil after 30 years of the experiment.

In variant with fertilizer rate $\mathrm{F} 2$, the available $\mathrm{P}$ increased slowly yet gradually and in 2012 reached $75.0 \mathrm{mg} \mathrm{P}_{2} \mathrm{O}_{5} \mathrm{~kg}^{-1}$ (Table 1). Available $\mathrm{K}$ enhanced rapidly and in 1992 stabilized, but during the last ten years the content of $\mathrm{K}$ started decreasing (Figure 1). The level of available $\mathrm{K}$ in 2012 was $108.0 \mathrm{mg} \mathrm{K} \mathrm{K}_{2} \mathrm{O}$ $\mathrm{kg}^{-1}$ and characterized as average.

In variant with fertilizer rate F3, the growth of available $P$ was faster than in variants with lower fertilizer rates. During first 10 years the content of $\mathrm{P}$ reached $67 \mathrm{mg} \mathrm{P}_{2} \mathrm{O}_{5} \mathrm{~kg}^{-1}$ (high level). The following ten years, available $\mathrm{P}$ increased very rapidly and reached $151 \mathrm{mg} \mathrm{P}_{2} \mathrm{O} \mathrm{kg}^{-1}$. In recent years the available $\mathrm{P}$ continued to increase to $174 \mathrm{mg}_{2} \mathrm{O} \mathrm{kg}^{-1}$ (Table 1). There was a slight rise. Available $\mathrm{K}$ intensified very rapidly and reached a high level within five years. During the next period, the plant available $\mathrm{K}$ increased slightly but gradually (Figure 1).

Long-term application of mineral fertilizers to agricultural soils can lead to accumulation of plant nutrients in soil. The proper amount of fertilizers is determined by the soil properties and crop needs.

There is a gradual decrease of stock of mobile phosphorus if phosphorus fertilizer is not used. On a low background of fertilizers (N45P30K45) a small decrease of mobile phosphorus in soil has only been observed in the recent years. At the rate of phosphorus P60 in soil the content gradually begins to grow and at the fertilizer rate P90 there is already a constant accumulation of mobile phosphorus in soil.

Exchangeable $\mathrm{K}$ content on non-fertilized plots declined slightly over the experimental period, but without reaching levels expected from nutrient balance estimates. Annual applications of $\mathrm{K}$ equal to average off take in yield were adequate to maintain available soil $\mathrm{K}$ content at its initial value. Potassium release kinetics for the exchangeable fraction, clearly discriminated between fertilized and non-fertilized treatments. These results highlight the role of $\mathrm{K}$ reserves readily available in soils and demonstrate the importance of cultural residues in $\mathrm{K}$ fertility management [7]. Exchangeable $\mathrm{K}$ leaching in the K225 treatment at $0-100 \mathrm{~cm}$ soil depth was the result of excessive $\mathrm{K}$ application or non-synchrony between $\mathrm{K}$ application and crop $\mathrm{K}$ demand. However, exchangeable $\mathrm{K}$ and non-exchangeable $\mathrm{K}$ at different soil depths are controlled by different physical, chemical and biological factors [9] like it is stated in our experiments about significant importance of fertilizer rate and factor of cultivar.

After 32 years the content of organic matter increased from $19-21 \mathrm{~g} \mathrm{~kg}^{-1}$ till $22-23 \mathrm{~g} \mathrm{~kg}^{-1}$ and there are no significant differences among fertilizing rates (Table 1).

TABLE 1

NUTRIENT CONTENT IN SOIL, 2012

\begin{tabular}{llll}
\hline & $\begin{array}{l}\text { Organic matter, } \\
\mathrm{g} \mathrm{kg}^{-1}\end{array}$ & $\begin{array}{l}\mathrm{Ca}, \\
\mathrm{mg} \mathrm{kg}^{-1}\end{array}$ & $\begin{array}{l}\mathrm{Mg}, \\
\mathrm{mg} \mathrm{kg}^{-1}\end{array}$ \\
\hline F0 & 22 & 670 & 68 \\
F1 & 23 & 1016 & 128 \\
F2 & 24 & 574 & 41 \\
F3 & 24 & 877 & 78 \\
\hline
\end{tabular}

There were no relation between different fertilizing rates and calcium and magnesium content in soil observed.

\section{CONCLUSIONS}

Long-term application of mineral fertilizers to agricultural soils can lead to accumulation of plant nutrients in soil.

The use of NPK fertilizers in 30 years' time resulted increase of content of exchangeable phosphorus in soil arable layer more than 20 times (from 9 till $184 \mathrm{mg} \mathrm{P}_{2} \mathrm{O}_{5} \mathrm{~kg}^{-1}$ ).

Exchangeable potassium in soil has increased more than 4 times (from 64 till $223 \mathrm{mg} \mathrm{K}_{2} \mathrm{O} \mathrm{kg}^{-1}$ ).

There were no relation between different fertilizing rates and calcium and magnesium content in soil observed

\section{ACKNOWLEDGEMENTS}

This work was supported by the European Regional Development Fund within the project Development of Technology of Reduction of Environmental Pollution Using Mineral Fertilizers (No. 2010/0232/2DP/2.1.1.1.0/10/APIA/VIAA/097).

\section{REFERENCES}

[1] Adomaitis T., Staugaitis G., Mažvila J., Vaišvila Z., Arbačiauskas J., Lubytė J., Šumskis D., Švėgžda A. Leaching of base cations is affected by a forty-year use of mineral 
fertilisation. Zemdirbyste-Agriculture 100(2), 2013, pp. 119126.

[2] Edhe L. 2012. Efficiency of phosphorus fertilization in longterm soil fertility experiments. Master Thesis. Swedish University of Agricultural Sciences; [cited 2014 Mai 22]. http://stud.epsilon.slu.se/4789/1/ehde 1 120910.pdf

[3] Grimvall A., Stålnacke P., Tonderski A. Time scales of nutrient losses from land to sea - a European perspective. Ecological Engineering 14(4), 2000, pp. 363-371.

[4] World reference base for soil resources 2006 http://www.fao.org/fileadmin/templates/nr/images/resources/pd f_docuents/wrb2007_red.pdf

[5] Jansons V., Abramenko K., Bērziṇa L., Timbare R. Risk assessment of the agricultural pollution with nitrates in Latvia. Proceedings of the Latvian University of Agriculture 22, 2009, pp. 1-11.

[6] Jansons V., Lagzdiņs A., Bērziņa L., Sudārs R., Abramenko K. Temporal and spatial variation of nutrient leaching from agricultural land in Latvia: long term trends in retention and nutrient loss in a drainage and small catchment scale. Scientific Journal of Riga Tehnical University: Environmental and Climate Tehnologies, 13, 2011, pp. 54-65.

[7] Jouany C., Colomb B., Bosc M. Long-term effects of potassium fertilization on yields and fertility status of calcareous soils of south-west France. European journal of agronomy. 5( 3-4), 1996, pp. 287-294.
[8] Mažvila J. Agrochemical properties of Lithuanian soils and their change: a monograph / compiled by Mažvila J. Lithuanian Institute of Agriculture, 1998, pp. 37-49 (Lithuanian)

[9] Qiu S., Xie J., Zhao S., Xu X., Hou Y., Wang X., Zhou W., He P., Johnston A. M., Christie P., Jin J. Long-term effects of potassium fertilization on yield, efficiency and soil fertility status in a rain-fed maize system in northeast China. Field crops research 163, 2014, pp. 1-9.

[10] Poulton P. R., Johnston A. E., White R. P. Plant-available soil phosphorus. Part I: the response of winter wheat and spring barley to Olsen $\mathrm{P}$ on a silty clay loam. Soil Use and Management, March 2013, 29, 4-11

[11] Stålnacke P., Grimvall A., Sundblad K., Tonderski A.. Estimation of riverine loads of nitrogen and phosphorus to the Baltic Sea, 1970-1993. Environmental Monitoring and Assessment 58(2), 1999, pp. 173-200.

[12] Stålnacke P., Pengerund A., Vassiljev A., Smedberg E., Mörth C.-M., Hägg H. E., Humborg C. Andersen H. E. Nitrogen surface water retention in the Baltic Sea drainage basin. Hydrology Earth System Sciences 11, 2014, pp. 10829-10858.

[13] Svanbäck A., Ulén B., Etana A. Mitigation of phosphorus leaching losses via subsurface drains from a cracking marine clay soil. Agriculture, Ecosystems \& Environment 184, 2014, pp. 124-134. 